\title{
РОЛЬ МАКРОЕЛЕМЕНТІВ КАЛЬЦІЮ ТА ФОСФОРУ В ХАРЧОВОМУ СТАТУСІ ПАЦІЄНТІВ РІЗНИХ ВІКОВИХ ГРУП, ЯКІ МЕШКАЮТЬ НА ТЕРИТОРІЯХ, РАДІОАКТИВНО ЗАБРУДНЕНИХ ВНАСЛІДОК АВАРІЇ НА ЧАЕС (Матеріали підготовлені до 35-річчя аварії на Чорнобильській атомній електростанції 26.04.1986 р.) (частина 1)
}

\author{
'MATАСАР І.Т., 'ПЕТРИЩЕНКО Л.М., 'MАТАСАР Т.В., ${ }^{2}$ МОЙСЕЄНКО В.О.
}

\author{
${ }^{1}$ ДУ “Національний науковий центр радіаційної медицини \\ Національної академії медичних наук України”, \\ ${ }^{2}$ Національний медичний університет імені О.О. Богомольця, Київ, Україна
}

Резюме Вступ. Дана робота присвячена проблемі порушення харчування населення різних вікових груп, яке мешкає на територіях, радіоактивно забруднених внаслідок аварії на ЧАЕС, зокрема недостатньому вмісту кальцію та фосфору.

Мета. Узагальнення відомостей про властивості мінеральних речовин, зокрема, кальцію та фосфору, їх добове споживання населенням різних вікових груп, яке мешкає на територіях, радіоактивно забруднених внаслідок аварії на ЧАЕС.

Матеріали та методи. Бібліографічний - проведено теоретичний аналіз та здійснено узагальнення даних літератури, проаналізовано фактичний вміст макроелементів у раціонах харчування різних вікових груп населення (дорослого працездатного, дитячого, вагітних жінок) із різних населених пунктів Іванківського району Київської області, яке мешкає на територіях, радіоактивно забруднених внаслідок аварії на ЧАЕС впродовж 2004-2018 рр. При дослідженні використано анкетно-опитувальний, математичний та статистичний методи.

Результати та їх обговорення. Встановлено, що фактичне надходження з раціоном харчування фосфору у вагітних жінок становило фосфору - 76\%. Щодо інших вікових груп дорослого населення, то надходження з раціоном харчування фосфору у чоловіків було вищим за фізіологічні потреби на $15 \%$, а у жінок було у межах фізіологічних норм. Вміст фосфору в харчуванні дітей, які мешкають в екологічно небезпечних регіонах України, задовольняв фізіологічні потреби. Втрачає організм людини фосфор переважно із сечею (60-65\% від величини, що надійшла із їжею). Знижується вміст фосфору в організмі хворих, які тривалий період вживали антацидні препарати, а також пацієнти, які мають проблеми з нирками, страждають на алкоголізм, вживають низькокалорійну їжу та мають хронічні хвороби. Всмоктування кальцію в організмі людини визначається іонізацією останнього і залежить від вмісту у продуктах харчування вітамінів A, C, D i F, а також магнію, фосфору і білку. Багато продуктів з високим вмістом кальцію одночасно багаті на вітамін D. У зв'язку із зазначеним, лише 20-30\% від вжитого кальцію засвоюється. Через його низьку біодоступність важко задовольнити фізіологічні потреби організму в цьому есенціальному елементі.

Висновки. Контроль добового споживання та корекція рівня кальцію і фосфору $є$ невід'ємними складовими впродовж всього життя людини, і вкрай необхідними у населення різних вікових груп, яке мешкає на територіях, радіоактивно забруднених внаслідок аварії на ЧАЕС, особливо у осіб з віковими змінами нирок.

Ключові слова: стан харчування, радіоактивно забрудненені території, вік, нирки.

Вступ.

За підрахунком Всесвітнього Банку, економічні збитки, пов'язані із неякісним та незбалансованим харчування через втрату здоров'я, можуть сягати 9\% валового національного продукту країни. [1, 2-4].
Серед факторів харчування, які мають важливе значення для підтримки здоров'я, працездатності та активного довголіття, особлива роль належить повноцінному і регулярному забезпеченню організму людини усіма необхідними поживними речовинами. [5-9] 
Зниження функції нирок починається у віці 40-45 років, коли в нирковій тканині і стінках дрібних судин посилено утворюється сполучна тканина, розвивається склероз ниркових клубочків і атрофія клітин ниркових канальців. Під час обстеження методами ультразвуку або комп'ютерної томографії спостерігається зменшення розміру нирок, наявність кіст в нирках, кількість і розмір яких з роками збільшується; нирки гірше виконують свої головні функції - виводять з організму кінцеві продукти обміну речовин і зайву рідину, регулюють обмін різних солей (наприклад, калію і натрію) і гормонів в організмі. Починаючи з віку 40 років, швидкість клубочкової фільтрації (ШКФ) щороку знижується приблизно на 0,75-1,0 мл/хв.

Особливу роль у фізіологічно оптимальному функціонуванні організму відіграють мінеральні речовини, що на рівні з іншими інгредієнтами їжі формують тканини живого організму, входять до складу ензимів та коензимів, гормонів, приймаючи участь у процесах утворення енергії, росту та відновлення організму. Утворення ферментів та реакції за їх участю відбуваються за обов'язкової участі мінеральних речовин $[10,11,12]$. Без них не відбувається підтримка кислотно-лужної рівноваги, не створюється фізіологічно необхідна концентрація іонів у клітинках організму та у міжклітинній рідині; вони генералізують та проводять нервові імпульси, діють як каталізатори хімічних процесів, регулюють активність ферментів тощо. [13-18].

Мінеральні речовини внутрішньоклітинної та міжклітинної рідин впливають на гомеостаз, остеогенез, приймають участь у процесах росту та відновлення організму, регулюють функціонування нервової системи та впливають на м'язовий тонус, що має надзвичайне значення для роботи серцево-судинної системи.

Метою дослідження $€$ узагальнення відомостей про властивості мінеральних речовин, добове споживання населенням різних вікових груп, яке мешкає на територіях, радіоактивно забруднених внаслідок аварії на ЧАЕС.

Матеріали і методи. Для досягнення поставленої мети використано такі матеріали і методи: бібліографічний - проведено теоретичний аналіз та здійснено узагальнення даних літератури, проаналізовано фактичний вміст макроелементів у раціонах харчування різних вікових груп населення (дорослого працездатного, дитячого, вагітних жінок) із різних населених пунктів Іванківського району Київської області, яке мешкає на територіях, радіоактивно забруднених внаслідок аварії на ЧАЕС впродовж 2004-2018 рр. При дослідженні використано анкетно-опитувальний, математичний та статистичний методи.

Результати та їх обговорення. Чорнобильська катастрофа - техногенна екологічно-гуманітарна катастрофа, спричинена двома тепловими вибухами і подальшим руйнуванням четвертого енергоблока Чорнобильської атомної електростанції, розташованої на території України (колишньої УРСР), в ніч на 26 квітня 1986 року.

В організмі людини містяться майже всі відомі у природі хімічні елементи. При цьому у найбільшій кількості присутні кисень, вуглець, водень, азот. Це так звані органічні елементи (вони формують майже 98\% хімічного вмісту клітини). Особливу групу складають макроелементи фосфор, калій, сірка, хлор, кальцій, магній, залізо, сумарна частка яких становить до 1,9\% від маси організму (табл. 1).

\section{Вміст у клітині та значення для організму макроелементів}

\begin{tabular}{|l|c|l|}
\hline \multicolumn{1}{|c|}{ Елемент } & $\begin{array}{c}\text { у \% від } \\
\text { загальної } \\
\text { маси клітини }\end{array}$ & \multicolumn{1}{|c|}{ Основне значення для організму } \\
\hline Фосфор (P) & $0,2-1,0$ & Входить до складу кісток, білків, нуклеїнових кислот, АТФ \\
\hline Калій (K) & $0,15-0,4$ & Основний позитивно заряджений іон в організмі \\
\hline Сірка (S) & $0,15-0,2$ & Входить до складу білків та інших біомолекул \\
\hline Хлор (Cl) & $0,05-0,1$ & Негативно заряджений іон в організмі \\
\hline Кальцій (Ca) & $0,04-2,0$ & $\begin{array}{l}\text { Основний компонент кісток, бере участь у реалізації метаболічних } \\
\text { процесів }\end{array}$ \\
\hline Магній (Mg) & $0,02-0,03$ & $\begin{array}{l}\text { Активує діяльність ферментів, структурний компонент хлорофілу. } € \\
\text { головним внутрішньоклітинним позитивно зарядженим іоном }\end{array}$ \\
\hline Залізо $(\mathrm{Fe})$ & $0,01-0,015$ & Входить до складу багатьох біомолекул, у тому числі гемоглобіну \\
\hline
\end{tabular}

Всі хімічні елементи, що містяться у клітинах живого організму, входять до складу органічних і неорганічних сполук або перебувають у вигляді іонів.
Більшість з цих процесів, при нестачі мінералів, призводять до виникнення незворотних змін. Так, дефіцит лише кальцію та цинку може призвести до 300 різних патологічних змін в організмі людини. 
Джерелом поживних речовин для організму людини є вода та їжа. Вміст мінералів в організмі з віком зростає, але у залежності від фізіологічного призначення та щільності тканини, їх концентрація відрізняється. Вміст мінералів в організмі людини коливається від мікрограмів до кілограмів (табл. 2).

Мінеральний склад організму дорослої людини вагою 70 кг

\begin{tabular}{|c|c|}
\hline Мінеральна речовина & Вага в організмі, $\mathbf{r}$ \\
\hline Кальцій $(\mathrm{Ca})$ & 1510 \\
\hline Фосфор $(\mathrm{P})$ & 840 \\
\hline Калій $(\mathrm{K})$ & 245 \\
\hline Сірка $(\mathrm{S})$ & 105 \\
\hline Хлор $(\mathrm{Cl})$ & 105 \\
\hline Натрій $(\mathrm{Na})$ & 105 \\
\hline Магній $(\mathrm{Mg})$ & 70 \\
\hline Залізо $(\mathrm{Fe})$ & 3,5 \\
\hline
\end{tabular}

Мінеральні речовини, вага яких в організмі людини сягає декількох грамів, відносяться до макроелементів. Тенденції до накопичення мінеральних речовин в організмі найвищі у період інтенсивного росту людини (17-20 років).

Мінеральні речовини із врахуванням функції, яку вони виконують, поділяють на незамінні (есенціальні), умовно незамінні, умовно токсичні та токсичні. До есенціальних відносять: залізо, мідь, цинк, селен, йод, кобальт, марганець, хром, молібден.

До умовно незамінніх - миш'як, бор, бром, фтор, літій, нікель, ванадій. Умовно токсичними та токсичними для організму людини вважаються - алюміній, свинець, кадмій, ртуть, берилій. Нестача в організмі певного або декількох мінералів визиває гіпо- чи мікроелементози, і навпаки, надлишок - гіперелементози.

Фосфор (лат. phosphorus), Р. Атомний номер у періодичній системі елементів Д. І. Менделєєва 15. Це металоїд, який, у залежності від умов, може проявляти окислювальні чи відновлювальні властивості. Ймовірно, завдяки цим ознакам він надзвичайно розповсюджений у рослинному та тваринному світах $[11,12]$.

В організмі дорослої людини до 86\% фосфору знаходиться у важкорозчинній формі у вигляді фосфату кальцію (гідроксилапатит), що і обумовлює мінеральну частину кісток скелету та зубів.

Таким чином, вміст фосфору в організмі людини вагою 70кг становить 780г, з цієї величини у скелеті міститься 700г, у м'язовій тканині - 50г, а в міжтканинному просторі та рідинах - 30г.

Половина засвоєного фосфору використовується на пластичні та обмінні процеси, що відбуваються у кістковій тканині, тобто 80-87\% від усього елементу міститься в апатиті (фосфат кальцію кісток). Зуби теж потребують фосфору у вигляді фторфосфату.

Співвідношення кальцію та фосфору в кістках має бути як 2:1. Лише 0,2\% фосфору циркулює у плазмі крові, яка з віком змінюється, що обумовлено гормональним фоном організму. Так, у дитячому віці рівень фосфору коливається від 5 до 6 мг на 100 мл крові, а у дорослих цей показник варірює від 2,5 до 3,5 мг на 100 мл відповідно.

Незадіяний у пластичних процесах кісток та зубів фосфор приймає участь в багатьох анаболічних та катаболічних процесах, зокрема:

- бере участь у різних метаболічних процеcax і відіграє важливу роль в життєдіяльності всіх живих організмів;

- входить до складу важливих біогенних сполук: нуклеотидів, нуклеїнових кислот та ряду вітамінів і фосфоліпідів, котрі відіграють важливу роль при утворені клітинних мембран і регулює їх проникність;

- виступає у ролі попередника при синтезі генетичних сполучень, зокрема ДНК та формуванні структури РНК;

- підкислює сечу, що протидіє утворенню ниркових каменів;

- приймає участь у створені буферної міжклітинної та внутрішньоклітинної рідин;

- сприяє трансмембранному транспорту рідин;

- сприяє утворенню високоенергетичних сполук, наприклад АТФ.

Вміст фосфору в крові $€$ одним із важливих показників мінерального обміну і виступає основною діагностичною ознакою ряду захворювань та патологічних станів, таких як рахіт, спазмофілія, гіпопаратиреоз, гіперпаратериоз, синдром Лейвуда-Олбрайта. В клінічній практиці широко застосовується визначення фосфору у крові та сечі пацієнта. При цьому у крові розрізняють 2 фракції фосфору: кислотно-розчинний та кислотно-нерозчинний.

У живих організмах фосфор п'ятивалентний. Він входить, головним чином, до складу фосфатів і, в меншій мірі, до статури піро- і поліфосфатів. Розчин фосфору входить до будови неорганічних речовин (фосфати калію та натрію) і деяких органічних сполук.

За добу з раціоном харчування ми отримуємо, в середньому, 1,2-2,4 г фосфору. Із всього спожитого фосфору засвоюється лише $70 \%$. Необхідно додати, що фосфор з риби всмоктується у кишківнику людини майже на 100\%. Кількість фосфору, що засвоюється із їжі, обернено пропорційна кількості кальцію, який є у раціоні. Жири та вітамін D, фітин і його похідні підсилю- 
ють всмоктування фосфору у початкових відділах тонкого кишківника.

Найбільш багаті фосфором (у мг на 100 г продукту): ікра осетрових риб - 594, яєчний жовток485, сири - від 390 до 460, яловича печінка - 316.

Із рослинних продуктів найбільша кількість фосфору (у мг на 100г продукту) містять: соєві боби - 700, квасоля - 504; крупи: вівсяна - 521, гречана - 422, рисова - 323; боби какао - 730; горіхи: кешью - 593, кедрові - 572, грецькі - 558, фісташки - 490, мигдаль - 483; насіння: гарбуза 1233, зародків пшениці - 1100, маку - 900, соняшника - 660.

Нашими багаторічними дослідженнями, проведеними серед населення різних вікових груп, які мешкають на екологічно небезпечних внаслідок аварії на ЧАЕС територіях України встановлено, що фактичне надходження з раціоном харчування фосфору у вагітних жінок становило фосфору - 76\%. Щодо інших вікових груп дорослого населення, то надходження з раціоном харчування фосфору у чоловіків було вищим за фізіологічні потреби на 15\%, а у жінок було у межах фізіологічних норм [19, 20].

Вміст фосфору в харчуванні дітей, які мешкають в екологічно небезпечних регіонах України, задовольняв фізіологічної потреби [21].

Втрачає організм людини фосфор переважно із сечею (60-65\% від величини, що надійшла із їжею).

Знижується вміст фосфору в організмі хворих, які тривалий період вживали антацидні препарати, а також пацієнти, які мають проблеми з нирками, страждають на алкоголізм, вживають низькокалорійну їжу та мають хронічні хвороби.

При надходженні в організм значної кількості фосфору, поглинання магнію знижується, що спонукає відкладання вапна в нирках, аорті та деяких тканинах організму.

В медичній практиці фосфор обмежено призначається. Для практичних цілей використовують препарати, що постачають клітинам фосфор або полегшують його доставку. Інколи достатнім $€$ введення в харчовий режим продуктів з високим вмістом фосфору, наприклад рибу. Серед препаратів з вмістом фосфору найбільш розповсюдженими є: аденозинтрифосфорна кислота, фітин, гліцерофосфат, фосфалюгель, таблетки: «Фосамакс», «Церебро-лецитин», «Ліпоцеребрин», «Вітрум», «Вітаспектрум» та інші.

Фармацевтичні препарати з вмістом фосфору в оптимальних дозах посилюють ріст і розвиток кісткової тканини; стимулюють кровообіг; гальмують окисні процеси та беруть участь в обміні речовин [11, 22-24].

Однак, перед їх вживанням, необхідно проконсультуватися з лікарем і підібрати оптимальний варіант дозування.
Кальцій (лат. calcium), Са. Атомний номер в періодичній системі елементів Д. І. Менделєєва 20. $€$ незамінним інгредієнтом при формуванні скелету організму, зубів, нігтів та волосся. Катіон кальцію - важливий регулятор обмінних процесів і функцій клітин, зокрема:

- активізує кальцієві канали;

- виступає антагоністом натрію, сприяє виведенню ряду металів та радіонуклідів;

- входить до складу молекул-перенощиків та транспортерів поживних речовини в клітину із навколо-клітинної рідини;

- контролює скорочення та розслаблення м'язів скелету;

- підтримує тонус судин, активізуючи діяльність гладкої мускулатури останніх;

- покращує функцію ряду життєво важливих ферментів, котрі відповідають за згортання крові та приймають участь в утворенні молекул АТФ;

- послаблює алергічні реакції шляхом підвищення реактивності (щільності) судин;

- $€$ потужним антиоксидантом та антистресором.

Обмін кальцію в здоровому організмі обумовлений фізичним навантаженням, віком, статтю та його вмістом в раціоні харчування [11, 12, 25-28].

Добова потреба кальцію залежно від віку наведено у табл. 3.

Таблиця 3 Добова потреба кальцію в залежності від віку

\begin{tabular}{|l|c|}
\hline \multicolumn{1}{|c|}{ Вік } & Потреба, мг/доба \\
\hline Діти 1-5 років & $800-900$ \\
\hline Діти 6-7 років & $1000-1200$ \\
\hline Дорослі & 800 \\
\hline Вагітні жінки & 1000 \\
\hline $\begin{array}{l}\text { Жінки, які вигодовують } \\
\text { материнським молоком }\end{array}$ & 1500 \\
\hline
\end{tabular}

Всмоктування кальцію в організмі людини визначається іонізацією останнього і залежить від вмісту у продуктах харчування вітамінів A, C, D i F, а також магнію, фосфору і білку. Багато продуктів з високим вмістом кальцію одночасно багаті на вітамін D $[29,30]$.

У зв'язку із зазначеним, лише 20-30\% від вжитого кальцію засвоюється. Через його низьку біодоступність важко задовольнити фізіологічні потреби організму в цьому есенціальному елементі.

Клінічні ознаки порушення обміну кальцію проявляються широкими симптомами, зокрема:

- викривленням хребта, кісток нижніх кінцівок (О- та Х-подібні ноги);

- високою пітливістю, дратівливістю (діти);

- гіпокальціємією новонароджених; 
- зниженням рівня фосфатів, у разі захворювання нирок;

- раннім облисінням та потьмянінням кольору волосся;

- тетанією (потужні м'язові скорочення), котрі можуть бути викликані алергічною реакцією, внаслідок отруєння свинцем.

Клінічне значення кальцію полягає в тому, що він:

- застосовується при порушенні росту скелету дітей;

- запобігає виникненню остеопорозу;

- утворює захист від кислот шлунку, діючи як пантоцид;

- підтримує ритм серця та скорочення м'язів;

- покращує засвоєння вітаміну $\mathrm{B}_{12}$;

- поліпшує ріст зубів;

- попереджає рак ободової кишки;

- призначається особам старшого віку при схильності до переломів кісток, а для молодих людей - при судомах литкових м'язів;

- протидіє ранньому руйнуванню емалі тощо [26, 31-35].

Джерелами кальцію (у мг на 100 г продукту) $€:$ молочні продукти - цільне сухе молоко (1155), сир твердий (від 880 до 1000), молоко - (120); рибні продукти - сардини (380), креветки, краби (від 90 до 100); квасоля (150); горіхи - мигдаль (273), фундук (188); насіння - кунжутне (1474), соняшника (367); фрукти, ягоди - інжир (144), хурма (127); овочі - зелений горошок (89); зелень петрушка (245), кріп (223), часник (180), шпинат (106).

За результатами наших досліджень встановлено, що вміст кальцію у раціонах харчування обстежених вагітних жінок, які мешкають у екологічно небезпечних внаслідок аварії на ЧАЕС регіонах становив в середньому $62 \%$ від фізіологічних потреб. Щодо інших категорій дорослого населення, то забезпеченість раціонів кальцієм у чоловіків становила 59\%, а у жінок - 63\% від фізіологічних потреб [19, 20].

Раціони дітей також вміщували недостатню кількість кальцію, незалежно від місця проживання та періоду дослідження і в середньому дефіцит цього нутрієнту складав від 35 до 48\% від фізіологічних норм [21].

Для пацієнтів, які мають ураження нирок, необхідне довгострокове спостереження. У спостереженні пацієнта повинен брати участь сімейний лікар, нефролог та інші фахівці. При ХХH 1-3ї стадій головні заходи - це регулярний контроль функції нирок і деяких інших аналізів (аналіз сечі, гемоглобін, калій, натрій, сечова кислота, кальцій, фосфор та ін.), строгий контроль рівня глюкози для пацієнта з цукровим діабетом; корекція оптимального артеріального кров'яного тиску, особливо для пацієнтів, у яких вже був знайдений білок в сечі, лікування загострень сечостатевих інфекцій та ін.). Якщо XXН все ж прогресує і ШКФ опускається нижче 45 мл/хв, додаються порушення роботи інших органів, наприклад анемія, пов'язані з XXН порушення обміну кальцію і зміни скелета, зміни серцево-судинної системи, кишечника та інших органів. Тому для літніх людей обов'язково спостереження у нефролога, щоб лікувати ці проблеми. Коли XXH досягла 4-ї стадії (ШКФ нижче 30 мл/хв), пацієнта потрібно проінформувати про початок замісної ниркової терапії (ЗПТ) в майбутньому і вибрати найбільш підходящий метод.

Висновки. Контроль добового споживання та корекція рівня кальцію і фосфору є невід'ємними складовими впродовж всього життя людини, і вкрай необхідними у населення різних вікових груп, яке мешкає на територіях, радіоактивно забруднених внаслідок аварії на ЧАЕС, особливо у осіб з віковими змінами нирок.

\section{ЛITEPATУРA}

1. Питание и здоровье в Европе. Новая основа для действий. Копенгаген: Всемирная организация здравоохранения. Европейское региональное бюро. Женева, 2003. -112 с.

2. Москаленко В.Ф. Пріоритетні напрями протидії глобальним загрозам громадському здоров'ю та міжнародна безпека в охороні здоров'я // Охорона здоров'я України. 2007. - № 1(25). - C. 9-11.

3. Грузєва О.В., Іншакова Г.В., Яковенко В. Г. Вплив харчових чинників на здоров'я населення // Главный врач. - 2008. - № 11. C. 71-72.

4. Comparative analysis of nutrition policies in the WHO European Region / A comparative analysis of nutrition policies and plants of action in Who European Member states, May 2006. - URL : http://www.euro.who.int/ data/assets/pdf_file/0004/149782/inst ambul_ conf_20ebd02.pdf.

5. Малая Л.Т., Ермакович И.И., Герасименко Ж.М. Профилактика хронических неинфекционных заболеваний в Украине. Современное состояние проблемы // Український терапевтичний журнал. - 2002. - Т.4, №3. - С. 5-7.

6. Гуліч М.П. Раціональне харчування та здоровий спосіб життя - основні чинники збереження здоров'я наснлення // Проблемы старения и долголетия. - 2011. - Т. 20, № 2. - С. 128-132.

7. Рингач Н.О. Громадське здоров'я як чинник національної безпеки: монографія. - К.: НАДУ, 2009. - 296 с. 
8. Shrimpton D.H. Nutritional implications of micronutrients interactions / D.H. Shrimpton // Chemist and Druggist. - 2004. - 15 May. P. 38-41.

9. Sandström B. Micronutrient interactions: effects on absorption and bioavailability / Brittmarie Sandström // British Journal of Nutrition. - 2001. - Vol. 85, Suppl. 2. - P. 181-185.

10. Микронутриенты в питании здорового и больного человека / В.А. Тутельян, В.Б. Спиричев, Б.П. Суханов, В.А. Кудашева. М.: Колос, 2002. - 424 с.

11. Ребров В.Г., Громова О.А. Витамины, макро- и микроэлементы. М.: ГЭОТАР-Медиа, 2008. 960 c.

12. Скальный А.В. Химические элементы в физиологии и экологии человека. / М.: Оникс 21 век, 2004. - 216 c.

13. Нанотехнології мікронутрієнтів: проблеми, перспективи та шляхи ліквідації дефіциту макро- та мікроелементів / А.М. Сердюк, М.П. Гуліч, В.Г. Каплуненко, М.В. Косінов // Журнал Національної академії медичних наук України. - 2010. - Т. 16, № 1. - С. 107-114.

14. Бабенко Г.А. Микроэлементозы человека: патогенез, профилактика, лечение // Микроэлементы в медицине. - 2001. - Т.2, №1. - C. 2-5.

15. Стрейн Дж. Микронутриенты: вопросы питания и хронические болезни // Вопр. питания. -2000 . - №3. - С. 43-45.

16. Рогинская Н.Ф., Богданец Е.С. Проблемы недостатка микроэлементов в питании современного человека и перспективы их преодоления // Наукові праці. - 2014. - Вип. 46, T. 1. - C. 187-191.

17. Богатырев А.Н., Пряничникова Н.С., Макеева И.А. Натуральные продукты питания -здоровье нации // Пищевая промышленность. - 2017. - №8. - С. 26-29.

18. Погожева А.В., Батурин А.К. Питание и профилактика неинфекционных заболеваний. Beau Bassin: Lambert Academic Publishing, 2017. - 184 c.

19. Нутріціологічна характеристика харчування вагітних жінок, які мешкають на радіоактивно забруднених територіях України / І.Т. Матасар, В.І. Матасар, Л.А. Горчакова, Л.М. Петрищенко, О.Г. Луценко // Науковий вісник Національного медичного університету ім. О.О. Богомольця. 2010. № 2-3. С. 62-68.

20. Мікронутрієнти як чинники розвитку преморбідних та морбідних станів у населення, що мешкає на радіоактивно забруднених територіях / І. Т. Матасар, Л. А. Горчакова, Л. М. Петрищенко, В. І. Матасар // Проблеми радіаційної медицини та радіобіології. 2007. Вип. 13. С. 239-245.

21. Корекція есенціальних нутрієнтних дефіцитів серед дітей та підлітків як засіб профілактики аліментарних та аліментарно залежних станів / І. Т. Матасар, В.І.Берзінь, В. І. Матасар, О. Г. Луценко // Семейная медицина. 2014. № 2(52). С. 139-142.

22. Щербак В.А., Каргина И.Г., Щербак Н.М. Маркеры метаболизма костной ткани при рахите // Российский вестник перинатологии и педиатрии. - 2020. № 65 (4). - С. 71-77.

23. Майданник В. Г. Рахит у детей: современные аспекты. - Киев, 2006. - 114 с.

24. Коровина Н.А., Захарова И.Н., Чебуркин А.В. Нарушения фосфорно-кальциевого обмена у детей. Проблемы и решения: руководство для врачей. М.: $2005-70$ с.

25. Спиричев В.Г. Витамины и минеральные вещества в питании и поддержании здоровья детей. М.: [б. и.], 2007. 22 с.

26. Коломиец В.В., Порхоменко Т.А. Соотношение потребления с пищей кальция и фосфора как фактор риска возникновения артериальной гипертонии // Укр. кардіол. журн. - 1996. - № 4. - С. 46-50.

27. Витебская А.В., Смирнова Г.Е., Ильин А.В. Витамин D и показатели кальций-фосфорного обмена у детей, проживающих в средней полосе России, в период максимальной инсоляции // Остеопороз и остеопатии. 2010. № 2. C. 4-9.

28. Коровина Н.А., Захарова И.Н., Чебуркин А.В. Нарушения фосфорно-кальциевого обмена у детей. Проблемы и решения: руководство для врачей. М.: $2005-70$ с.

29. Поліщук Т.В., Гуліч М.П., Карпенко Л.О. Гігієнічна оцінка особливостей мікронутрієнтного складу молока та традиційних кисломолочних продуктів вітчизняного виробництва // Гігієна наслених місць. - 2012. - Вип. 60. - С. 229-236.

30. Кандинская Е.С., Редькин С.В., Чебакова Г.В. Мониторинг содержания кальция в сыром молоке коров // Ветеринария сегодня. - 2019. - № 1. - C. 29-33. URL: https://doi. org/10.29326/2304-196X-2019-1-28-29-33

31. Кудрин А.В. Микроэлементы и кальций в регуляции апоптоза // УСБ. - 1998. - № 5. C. 17-21.

32. Кукс В.Г., Тутельян А.А. Витамины и микроэлементы в клинической фармакологии. М.: Палея, 2001. - 214 с.

33. Fenech M., Fergason L.R. Vitamin/minerals and genomic stability in humans // Mutat. Res. - 2001. - N 475. - P. 1-6. 
34. Защитное действие витаминов при индуцированном мутагенезе / А.Д. Дурнев, Е.С. Сиднева, А.К. Жанатаев и др. // Вестн. Poc. AMH. - 2006 - № 7. - C. 6-13.

35. Скальный А.В., Быков А.Т., Яцык Г.В. Микроэлементы и здоровье. Москва. 2002. $133 \mathrm{c}$

\section{PЕЗЮME}

\section{РОЛЬ МАКРОЭЛЕМЕНТОВ КАЛЬЦИЯ И ФОСФОРА В ПИЩЕВОМ СТАТУСЕ ПАЦИЕНТОВ РАЗНЫХ ВОЗРАСТНЫХ ГРУПП, ПРОЖИВАЮЩИХ НА ТЕРРИТОРИЯХ, РАДИОАКТИВНО ЗАГРЯЗНЕННЫХ ВСЛЕДСТВИЕ АВАРИИ НА ЧАЭС}

(Материалы подготовлены к 35-летию аварии на Чернобыльской атомной электростанции 26.04.1986 г.)

'Матасар И.Т., 'Петрищенко Л.М., 'Матасар Т.В., ${ }^{2}$ Мойсеенко B.A.

'ДУ «Национальный научный центр радиационной медицины Национальной академии медицинских наук Украины»,

${ }^{2}$ Национальний медицинский университет имени А.А. Богомольца (Киев, Украина)

Введение. Данная работа посвящена проблеме нарушения питания населения различных возрастных групп, проживающего на территориях, радиоактивно загрязненных вследствие аварии на ЧАЭС, в частности недостаточном содержании кальция и фосфора.

Цель. Обобщение сведений о свойствах минеральных веществ, в частности, кальция и фосфора, их суточное потребление населением различных возрастных групп, проживающего на территориях, радиоактивно загрязненных вследствие аварии на ЧАЭС.

Материалы и методы. Библиографический - проведен теоретический анализ и осуществлено обобщение данных литературы, проанализированы фактическое содержание макроэлементов в рационах питания различных возрастных групп населения (взрослого трудоспособного, детского, беременных женщин) из разных населенных пунктов Иванковского района Киевской области, проживающего на территориях, радиоактивно загрязненных вследствие аварии на ЧАЭС в течение 2004-2018 гг. При исследовании использованы анкетно-опросный, математический и статистический методы.

Результаты и их обсуждение. Установлено, что фактическое поступление с рационом питания фосфора у беременных женщин составило фосфора 76\%. Что касается других возрастных групп взрослого населения, то поступления с рационом питания фосфора у мужчин было выше физиологической потребности на 15\%, а у женщин было в пределах физиологических норм. Содержание фосфора в питании детей, проживающих в экологически опасных регионах Украины, удовлетворял физиологической потребности. Теряет организм человека фосфор преимущественно с мочой (60-65\% от величины, поступившей с пищей). Снижается содержание фосфора в организме больных, длительный период употреблявших антацидные препараты, а также пациенты, имеющие пробле- мы с почками, страдающих алкоголизмом, употребляющих низкокалорийную пищу и имеющие хронические болезни. Всасывание кальция в организме человека определяется ионизацией последнего и зависит от содержания в продуктах питания витаминов A, C, D и F, а также магния, фосфора и белка. Многие продукты с высоким содержанием кальция одновременно богаты витамином D. В связи с указанным, лишь 20-30\% от употребленного кальция усваивается. Изза его низкой биодоступности, трудно удовлетворить физиологические потребности организма в этом эссенциальных элементе.

Выводы. Контроль суточного потребления и коррекция уровня кальция и фосфора являются неотъемлемыми составляющими на протяжении всей жизни человека, и крайне необходимыми у населения различных возрастных групп, проживающего на территориях, радиоактивно загрязненных вследствие аварии на ЧАЭС, особенно у лиц с возрастными изменениями почек.

Ключевые слова: состояние питания, радиоактивно загрязненные территории, возраст, почки.

\section{SUMMARY}

\section{THE ROLE OF MACROELEMENTS CALCIUM AND PHOSPHORUS IN THE NUTRITIONAL STATUS OF PATIENTS WITH AGE CHANGES IN KIDNEYS LIVING IN TERRITORIES RADIOACTIVELY CONTAMINATED DUE TO THE CHNPP ACCIDENT}

(Materials prepared for the 35th anniversary of the accident at the Chernobyl nuclear power plant 26.04. 1986) (Part 1)

'Matasar I.T., 'Petrishchenko L.M., 'Matasar T.V., ${ }^{2}$ Moyseyenko V.O.

${ }^{1} \mathrm{DU}$ «National Research Center for Radiation Medicine National Academy of Medical Sciences of Ukraine",

${ }^{2}$ Bogomolets National Medical University (Kyiv, Ukraine)

Introduction. This work is devoted to the problem of malnutrition of the population of different age groups living in territories radioactively contaminated as a result of the Chernobyl accident, in particular, the insufficient content of calcium and phosphorus.

Goal. Generalization of information about the properties of minerals, in particular, calcium and phosphorus, their daily consumption by the population of different age groups living in territories radioactively contaminated as a result of the Chernobyl accident.

Materials and Methods. Bibliographic - a theoretical analysis was carried out and the literature data were generalized, the actual content of macronutrients in the diets of various age groups of the population (workingage adult, children, pregnant women) from different settlements of the Ivankovsky district of the Kiev region, living in territories radioactively contaminated as a result of the Chernobyl accident, was analyzed during 2004-2018 The study used questionnaire, mathematical and statistical methods.

Results and discussion. It was found that the actual intake of phosphorus with the diet in pregnant women was phosphorus $-76 \%$. As for other age groups of the adult population, the intake of phosphorus from the diet 
in men was higher than the physiological requirements by $15 \%$, and in women it was within the physiological norms. The phosphorus content in the diet of children living in ecologically dangerous regions of Ukraine satisfied the physiological needs. The human body loses phosphorus mainly with urine $(60-65 \%$ of the amount ingested with food). The content of phosphorus in the body of patients decreases, they have used antacids for a long period, as well as patients with kidney problems, alcoholism, lowcalorie foods and have chronic diseases. The absorption of calcium in the human body is determined by the ionization of the latter and depends on the content of vitamins A, C, D and F in food, as well as magnesium, phosphorus and protein. Many foods with a high calcium content are simultaneously rich in vitamin $\mathrm{D}$. In connection with this, only $20-30 \%$ of the calcium consumed is absorbed. Due to its low bioavailability, it is difficult to satisfy the physiological needs of the body for this essential element.

Conclusions. Control of daily consumption and correction of calcium and phosphorus levels are integral components throughout a person's life, and are extremely necessary for the population of various age groups living in territories radioactively contaminated as a result of the Chernobyl accident, especially for people with age-related changes in the kidneys.

Key words: nutritional status, radioactively contaminated areas, age, kidneys.

\section{АВТОРСЬКА ДОВІДКА}

\section{Матасар Ігнат Тимофійович}

ду “Національний науковий центр радіаційної медицини Національної академії медичних наук України",

д.м.н., професор

Адреса: проспект Перемоги, 119, Київ, 02000

E-mail: matasar.it@gmail.com

\section{Петрищенко Л.М.}

ДУ “Національний науковий центр радіаційної медицини Національної академії медичних наук України", к.б.н., вчений секретар IEP ННЦРМ Адреса: проспект Перемоги, 119, Київ, 02000

E-mail: matasar.it@gmail.com

\section{Матасар Тетяна Вікторівна}

ДУ “Національний науковий центр радіаційної медицини Національної академії медичних наук України", лікар-педіатр вищої категорії Адреса: проспект Перемоги, 119, Київ, 02000

моб:-380674662818

E-mail: matasar.it@gmail.com

\section{Мойсеєнко Валентина Олек- сіївна}

Національний медичний університет імені О.О. Богомольця, академік НАН ВО України, д.м.н., професор моб.: +380677779249:

E-mail: moyseyenko_vo@ukr.net

\author{
Матасар Игнат Тимофеевич \\ ГУ «Национальный научный \\ центр радиационной медицины \\ Национальной академии \\ медицинских наук Украины», д.м.н., \\ профессор \\ Адрес: Проспект Победы, 119, \\ Киев, 02000 \\ E-mail: matasar.it@gmail.com
}

\section{Петрищенко Л.М.}

ГУ «Национальный научный центр радиационной медицины Национальной академии медицинских наук Украины», к.б.н., учёный секретарь ИЭР ННЦРМ Адрес: Проспект Победы, 119, Киев, 02000

E-mail: matasar.it@gmail.com

\section{Матасар Татьяна Викторовна}

ГУ «Национальный научный центр радиационной медицины Национальной академии медицинских наук Украины», врач-педиатр высшей категории

Адрес: Проспект Победы, 119, Киев, 02000

моб.: + 380674662818

E-mail: matasar.it@gmail.com

\section{Мойсеенко Валентина Алек- сеевна}

Национальный медицинский университет

имени А.А. Богомольца, академик

НАН ВО Украины, д.м.Н., профессор моб .: +380677779249:

E-mail: moyseyenko_vo@ukr.net

\section{Matasar Ignat}

SI "National Research Center for Radiation Medicine National Academy of Medical Sciences of Ukraine",

MD, Professor

Address: 119 Peremohy Avenue, Kyiv, 02000

E-mail: matasar.it@gmail.com

\section{Petrishchenko L.}

SI "National Research Center for Radiation Medicine

National Academy of Medical Sciences of Ukraine", Ph.D., Scientific Secretary of the IER NSCRM

Address: 119 Peremohy Avenue, Kyiv, 02000

E-mail: matasar.it@gmail.com

\section{Matasar T.}

SI "National Research Center for Radiation Medicine National Academy of Medical Sciences of Ukraine" , pediatrician of the highest category Address: 119 Peremohy Avenue, Kyiv, 02000

mob: + 380674662818

E-mail: matasar.it@gmail.com

\section{Moyseyenko Valentyna}

Bogomolets National Medical University, MD, PhD, Professor, Academician of the National Academy of Sciences of Ukraine mob.: +380677779249

E-mail: moyseyenko_vo@ukr.net 